\title{
Enhanced thrombin generation in patients receiving intensive care
}

\author{
Ganapathy Balakrishnan, Joyce Brownlie, Richard Webber, Brenda Gibson
}

\begin{abstract}
Thrombin-antithrombin III complex (TAT) concentration was measured in 27 control and 155 intensive care patients to (a) establish normal reference ranges, (b) measure thrombin generation in critically ill patients, and (c) determine the characteristics of the TAT assay for the diagnosis of disseminated intravascular coagulation (DIC) in children.

The normal reference range was $1-4.3 \mu \mathrm{g} / 1$ (median $2 \cdot 3 \mu \mathrm{g} / \mathrm{l}$ ), and $89.7 \%$ of patients had raised TAT concentrations. Median TAT concentrations in the presence of DIC (27 $\mu \mathrm{g} / \mathrm{l})$ were significantly higher than in its absence $(8 \mu \mathrm{g} / \mathrm{l})$. Sensitivity, specificity, and positive and negative predictive values of the assay were $97 \cdot 3 \%, 28 \cdot 3 \%, 76 \cdot 3 \%$, and $81 \cdot 3 \%$, respectively, at a cut off of $4 \mu \mathrm{g} / \mathrm{l}$.

Excess thrombin production occurs in the majority of critically ill children. The TAT assay is potentially useful in the diagnosis of DIC in children.
\end{abstract}

Disseminated intravascular coagulation (DIC) occurs as an epiphenomenon in many disorders which necessitate admission to the intensive care unit, such as infections, massive tissue trauma, malignancy, postoperative states, vasculitis, and severe acute haemolysis ${ }^{1}$; and it is frequently fatal. ${ }^{2} 3 \mathrm{DIC}$ is initiated by excessive thrombin generation and is characterised by fibrin deposition in the microvasculature, consumption of haemostatic factors, and activation of fibrinolysis.

Current diagnostic tests for DIC are insensitive and non-specific, ${ }^{4}$ and measurement of in vivo thrombin generation and/or fibrinolysis may be more useful. D-dimers (the $D$ fragments of fibrinogen) are more specific markers for DIC than are fibrin degradation products ${ }^{5}$ but are indirect measures of hypercoagulability. Thrombin is inactivated in vivo by antithrombin III to form an inactive complex, thrombin-antithrombin III complex (TAT). Measurement of

Royal Hospital for Sick Children, Yorkhill, Glasgow G3 8SJ, Intensive Care Ünit Ganapathy Balakrishnan

Department of Haematology Joyce Brownlie

Richard Webber

Brenda Gibson

Correspondence to: Dr Gibson.

Accepted 2 September 1991
TAT may give an earlier and more direct indication of a prethrombotic state. TAT concentrations have been measured in DIC and other prethrombotic states in adults ${ }^{12-14}$ but there are only anecdotal reports in children.

The purpose of this study was to (a) establish normal reference ranges for TAT in children, (b) measure thrombin generation in a group of children at high risk of DIC, and (c) determine the characteristics of the TAT assay for the diagnosis of DIC.

\section{Patients and methods} PATIENTS

A prospective study was made of 155 children admitted consecutively to our intensive care unit, and 27 healthy children having elective minor surgery (for example, circumcision) acted as controls. In the first 19 patients paired samples were collected to test the variations in TAT concentrations with two commonly used anticoagulants. The study was approved by the hospital ethics committee.

\section{BLOOD COLLECTION}

Samples were collected by direct venepuncture as soon as possible after admission before the administration of blood or blood products. Blood was collected in standard $2 \mathrm{ml}$ coagulation tubes (Teklab) containing $0 \cdot 11 \mathrm{M}$ trisodium citrate (nine parts blood to one part citrate). For paired samples, additional $2 \mathrm{ml}$ bottles (Sarstedt) containing solid dipotassium EDTA $(1.6 \mathrm{mg} / \mathrm{ml}$ of blood) were used.

\section{SAMPLE PREPARATION}

Samples were centrifuged within one hour of collection at $3000 \mathrm{rpm}(1200-1500 \mathrm{~g})$ for 15 minutes. Two $300 \mu \mathrm{l}$ aliquots of plasma were separated into $2 \mathrm{ml}$ polypropylene cryopreservation tubes and frozen initially at $-20^{\circ} \mathrm{C}$. Within six hours both $300 \mu$ l aliquots were transferred to $-70^{\circ} \mathrm{C}$. One $50 \mu \mathrm{l}$ aliquot was frozen at $-20^{\circ} \mathrm{C}$. D-dimers were run in batches within 24 hours using the frozen $50 \mu$ l aliquot. TAT assays were performed on specimens stored at $-70^{\circ} \mathrm{C}$. Coagulation screens were performed within two hours of sample collection.

\section{ASSAYS}

TAT

The commercially available kit (EnzygnostTAT, Behringwerke AG, Marburg, Germany) was used. The test is an enzyme immunoassay based on the sandwich principle. The normal reference range for adults is $1-4 \cdot 1 \mu \mathrm{g} / \mathrm{l}$.

\section{D-dimers}

Agen Dimertest Latex Kit (Agen Biomedical Ltd) was used. The test is a slide agglutination test using polystyrene latex beads coated with $D$ dimer antibody and $10 \mu \mathrm{l}$ of plasma. A positive test is indicated by agglutination at 3 minutes.

\section{Other assays}

Microassays for prothrombin time, activated partial thromboplastin time, thrombin clotting time, and fibrinogen were carried out on all samples using the methods described by 
Johnston and Zipursky. ${ }^{15}$ Platelet counts were measured using a Sysmex M2000 cell counter.

CRITERIA FOR DIC

DIC was diagnosed if at least two of the following were present: prothrombin time $>\mathbf{2 0}$ $\mathrm{s}$, activated partial thromboplastin time $>50 \mathrm{~s}$, fibrinogen $<1.5 \mathrm{~g} / \mathrm{l}$, platelets $<150 \times 10^{9} / 1$ or $\mathrm{D}$ dimers $>0.2 \mathrm{mg} / \mathrm{l}$.

\section{STATISTICAL METHODS}

Inter group variations in TAT were compared using one way analyses of variance (ANOVA) followed by multiple range analysis (Scheffe's test). Continuous variables were compared using the Mann-Whitney U test. Spearman's rank correlation was used to test the relationship between TAT and concurrently assayed coagulation parameters. Sensitivity, specificity, positive predictive value, and negative predictive value were calculated at different cut off values of TAT. The level of statistical significance was taken as $\mathrm{p}<0.05$.

\section{Results}

EFFECTS OF DIFFERENT ANTICOAGULANTS ON TAT CONCENTRATIONS

No significant differences in TAT concentrations were seen in the 19 paired samples collected into trisodium citrate or dipotassium EDTA (difference between medians $=0 \cdot 2$, $p=0.31$ ). Hence in all other patients only citrated samples were collected.

\section{CONTROLS}

The 27 control children had a median age of 18 months (range 3 days to 12 years). All had normal coagulation by standard assays (that is, prothrombin time $<18 \mathrm{~s}$, activated partial thromboplastin time $<48 \mathrm{~s}$, thrombin clotting time $<13 \mathrm{~s}$, fibrinogen $>1.5 \mathrm{~g} / 1$ and $\mathrm{D}$-dimers $<0.2 \mathrm{mg} / \mathrm{l}$ ) and normal platelet counts. The median TAT concentration in these children was $2 \cdot 3 \mu \mathrm{g} / 1$ (range $1-4 \cdot 3 \mu \mathrm{g} / \mathrm{l}$ ) and they showed no age or sex related differences.

\section{PATIENTS}

The median age of the 155 patients ( 96 male, 59 female) was 21 months (range 3 days to 18.6 years). There were 85 admitted postoperatively and 70 had a variety of disorders.

Overall, 139 out of 155 patients $(89 \cdot 7 \%)$ had raised TAT concentrations $(>4 \cdot 3 \mu \mathrm{g} / \mathrm{l})$. Median TAT concentrations were above normal in all major diagnostic categories of patients without significant variations in relation to diagnosis (table 1).

\section{TAT CONCENTRATIONS IN DIC}

DIC was diagnosed in $110(71 \%)$ patients using the criteria described above. Of these, 14 patients had fulminant DIC manifested by frank bleeding, multiorgan failure, and grossly deranged coagulation. The remaining 96 patients had low grade DIC ( 36 with laboratory but no clinical evidence of DIC, and 60 with minor bruising only). The median TAT concentration in DIC was $27 \mu \mathrm{g} / 1$ (range $3 \cdot 8-70 \mu \mathrm{g} / \mathrm{l})$. In 45
Table 1 Incidence of DIC and TAT concentrations in different diagnostic groups

\begin{tabular}{|c|c|c|c|c|}
\hline \multirow{2}{*}{$\begin{array}{l}\text { Diagnostic } \\
\text { group }\end{array}$} & \multirow[t]{2}{*}{ No } & \multirow[t]{2}{*}{$D I C$} & \multicolumn{2}{|c|}{$T A T(\mu g / l)$} \\
\hline & & & Median & Range \\
\hline $\begin{array}{l}\text { Postoperative } \\
\text { Septicaemia } \\
\text { Viral infections } \\
\text { Bacterial infections } \\
\text { (without septicaemia) }\end{array}$ & $\begin{array}{l}85 \\
17 \\
13 \\
10\end{array}$ & $\begin{array}{r}64 \\
17 \\
2 \\
6\end{array}$ & $\begin{array}{l}21 \\
23 \\
12 \cdot 4 \\
11 \cdot 3\end{array}$ & $\begin{array}{l}3 \cdot 4-60 \\
3 \cdot 2-66 \\
1 \cdot 8-70 \\
3 \cdot 8-70\end{array}$ \\
\hline $\begin{array}{l}\text { Malignancy } \\
\text { Trauma } \\
\text { Miscellaneous }\end{array}$ & $\begin{array}{r}5 \\
4 \\
21\end{array}$ & $\begin{array}{r}5 \\
4 \\
12\end{array}$ & $\begin{array}{l}21 \\
20 \cdot 5 \\
18 \cdot 4\end{array}$ & $\begin{array}{c}3 \cdot 4-70 \\
12-70 \\
2 \cdot 3-60\end{array}$ \\
\hline Controls & 27 & 0 & $2 \cdot 3$ & $1-4 \cdot 3$ \\
\hline
\end{tabular}

(29\%) patients there was no clinical evidence or laboratory evidence of DIC. The median TAT concentration in these patients was $8 \mu \mathrm{g} / \mathrm{l}$ (range $1.8-70 \mu \mathrm{g} / \mathrm{l})$. TAT concentrations in the presence of DIC were thus considerably higher than in its absence $(p<0.0001)$. The values obtained in both groups of patients were significantly higher than in controls $(p<0.001)$. There was a correlation between maximum TAT concentrations and severity of DIC. The highest concentrations were recorded in fulminant DIC. Concentrations of $>60 \mu \mathrm{g} / \mathrm{l}$ (the upper limit of detection in undiluted plasma) were recorded in $50 \%$ of patients with fulminant DIC and $18 \cdot 7 \%$ of patients with low grade DIC, but only $4 \cdot 3 \%$ of patients without DIC. There was no correlation between TAT concentrations and outcome. The sensitivity, specificity, and the positive and negative predictive values of the TAT assay for the diagnosis of DIC at different cut offs is shown in table 2. At a cut off of $4 \mu \mathrm{g} / 1$ (95th centile of the control group) the values were: $97 \cdot 3 \%, 28 \cdot 3 \%, 76 \cdot 3 \%$, and $81 \cdot 3 \%$ respectively. At higher cut offs there is an improvement in specificity and positive predictive value but a fall in the sensitivity and negative predictive value, most noticeable above a cut off of $10 \mu \mathrm{g} / \mathrm{l}$.

\section{CORRELATION OF TAT WITH OTHER COAGULATION PARAMETERS}

There was a moderately significant positive correlation between TAT and concurrently assayed prothrombin time $(r=0.51, p<0.001)$ and activated partial thromboplastin time $(r=0.42, p<0.001)$, a weak but significant correlation with $\mathrm{D}$-dimers $(\mathrm{r}=0.24, \mathrm{p}=0.002)$, and a moderately significant negative correlation with fibrinogen $(r=-0.41, p<0.001)$ and platelets $(r=-0.32, p<0.001)$.

\section{Discussion}

Thrombin generation represents a pivotal event in coagulation. Thrombin cleaves fibrinopeptide $A$ and $B$ from fibrinogen, leaving soluble fibrin monomer which polymerises rapidly to form the

Table 2. Characteristics of the TAT assay for the diagnosis of DIC

\begin{tabular}{rllll}
\hline $\begin{array}{l}\text { TAT } \\
(\mu g / l)\end{array}$ & $\begin{array}{l}\text { Sensitivity } \\
(\%)\end{array}$ & $\begin{array}{l}\text { Specificity } \\
(\%)\end{array}$ & $\begin{array}{l}\text { Positive } \\
\text { predictive } \\
\text { value (\%) }\end{array}$ & $\begin{array}{l}\text { Negative } \\
\text { predictive } \\
\text { value (\%) }\end{array}$ \\
\hline 4 & $97 \cdot 3$ & $28 \cdot 3$ & $76 \cdot 3$ & $81 \cdot 3$ \\
5 & $94 \cdot 5$ & $34 \cdot 7$ & $77 \cdot 4$ & $72 \cdot 7$ \\
10 & $83 \cdot 5$ & $58 \cdot 7$ & $82 \cdot 7$ & 60 \\
20 & 56 & $71 \cdot 7$ & $82 \cdot 4$ & $40 \cdot 7$ \\
40 & $38 \cdot 5$ & $86 \cdot 9$ & $87 \cdot 5$ & $37 \cdot 4$ \\
60 & 23 & $95 \cdot 6$ & $92 \cdot 6$ & $34 \cdot 4$ \\
\hline
\end{tabular}


fibrin clot. It also activates factor XIII which catalyses the formation of stable fibrin polymer. ${ }^{16}$ Antithrombin III inhibits thrombin (to form TAT) as well as factors IXa, Xa, XIa, and XIIa and thus modulates the activity of the coagulation system. ${ }^{17-20}$

TAT concentrations seemed to be uninfluenced by the choice of anticoagulant. After obtaining the results on the first 19 patients, it was deemed necessary to use only citrated samples. This gave us the advantage of obtaining a coagulation screen and TAT value on a single $2 \mathrm{ml}$ sample of blood.

Low grade generation of thrombin is a normal phenomenon in children and we were able to establish a normal reference range of $1-4 \cdot 3 \mu \mathrm{g} / \mathrm{l}$. This is very similar to the normal adult reference range quoted by the manufacturers although concentrations of $0 \cdot 85-3 \cdot 2 \mu \mathrm{g} / 1$ and $2 \cdot 1-9 \cdot 9 \mu \mathrm{g} / \mathrm{l}$ have been recorded by Pelzer $e t$ $a l^{7}$ and Boisclair et $a l,{ }^{21}$ respectively, in healthy adults.

Excessive thrombin generation was present in as many as $\mathbf{9 0 \%}$ of critically ill children with a variety of underlying disorders, indicating an underlying prethrombotic state. The sample of children in this study was representative of the population admitted annually to our paediatric intensive care unit and included two groups (viral infections and bacterial infections without septicaemia) not previously shown to be associated with raised TAT concentrations. The action of thromboplastins generated by trauma, shock, hypoxia, burns, or sepsis potentiates this prethrombotic state, and together with the reticuloendothelial blockade which is common in critically ill children makes the triggering of DIC particularly likely. ${ }^{22}$ This was confirmed by the high incidence $(71 \%)$ of DIC in these children.

As expected, median TAT concentrations were significantly higher in the presence of DIC than in its absence, all but three of the 110 children $(\mathbf{9 7} \cdot 3 \%$ ) with DIC in our study having raised TAT concentrations. The incidence of raised TAT concentrations in adults with DIC has been variably reported between $61 \%$ and $97 \% .2621$

The sensitivity of TAT for the diagnosis of DIC has ranged from $80 \%$ to $96.7 \%$ and the specificity from $39 \%$ to $63 \%$ in adult studies, ${ }^{26}$ explained in part by the different diagnostic criteria used for defining DIC and different cut offs of TAT employed. We selected our criteria to include cases of low grade DIC. Using our criteria, the specificity of the assay at a cut off of $4 \mu \mathrm{g} / \mathrm{l}$ was low $(28 \cdot 3 \%$ ), although the sensitivity was high $(97 \cdot 3 \%)$. Because critically ill children produce excess thrombin even when DIC is not present, a higher cut off $(10 \mu \mathrm{g} / \mathrm{l})$ may be more appropriate in children. At this level, even though there is some loss of sensitivity, the specificity and the positive predictive value (which indicates the degree of confidence in the diagnosis based on a positive assay result) are considerably improved.

The correlation of TAT with other coagulation parameters reflects the high incidence of DIC in our patients, but we found a much weaker correlation with D-dimers than previously reported in adult studies, ${ }^{21}$ either because complete neutralisation of thrombin by antithrombin III had taken place or fibrinolysis, being a later event had not yet occurred. Our study was confined to single samples taken soon after admission. This may not be optimal, and some cases of developing DIC may have been missed. Estimating TAT on serial samples may be more useful both in detecting these cases and in monitoring the efficacy of treatment of DIC; TAT concentrations would be expected to fall as clinical improvement took place.

Our study confirms that as in adults, the TAT assay is potentially useful in the diagnosis of DIC in children. Its role in monitoring the treatment of DIC needs to be further evaluated.

1 Egbring $R$, Seitz $R$, Blanke $H$, et al. The proteinase inhibitor complexes (antithrombin III-thrombin; $\alpha_{2}$ antiplasminplasmin and $\alpha_{1}$ antitrypsin-elastase) in septicaemia, fulminant hepatic failure and cardiac shock: value for diagnosis and therapy control

2 Hoek JA, Sturk A, Wouterten Cate J, Lamping RJ, Berends $\mathrm{F}$, Borm JJJ. Laboratory and clinical evalution of an assay of thrombin-antithrombin III complexes in plasma. Clin Chem 1988;34:2058-62.

3 Spero JA, Lewis JH, Hasiba U. Disseminated intravascular coagulation: findings in 346 patients. Thromb Haemost 1980;43:28-33.

4 Feinstein DI. Diagnosis and management of disseminated intravascular coagulation: the role of heparin therapy. Blood 1982;60:284-7.

5 Carr JM, McKinney $M$, McDonagh J. Diagnosis of disseminated intravascular coagulation. Am $\mathcal{f}$ Clin Patho 1989;91:280-7.

6 Dati F, Pelzer H, Barthels M, et al. Multicenter evaluation of a new enzyme immunoassay for determination of the thrombin-antithrombin III complex (TAT). Haemostasis 1988;18:130-1.

7 Pelzer H, Schwarz A, Heimburger N. Determination of human thrombin-antithrombin III complex in plasma with an enzyme-linked immunosorbent assay. Thromb Haemost 1988;59:101-6.

8 Bounameaux H, Slosman D, de Moerloose P, Reber G. Laboratory diagnosis of pulmonary embolism: value of increased levels of plasma D-dimer and thrombin-antithrombin III complexes. Biomed Pharmacother 1989;43: thrombin.

9 Seitz $R$, Wolf $M$, Egbring $R$, Havemann $K$. The disturbance of hemostasis in septic shock: role of neutrophil elastase of hemostasis in septic shock: role of neutrophil elastase and thrombin, effects of antithrombin III
substitution. Eur f Haematol 1989;43:22-8.

10 Egbring $R$, Seitz $R$, Blanke $H$, et al. Immunologica determination of proteinase inhibitor complexes (PIC's) and their behaviour during plasma derivate treatment in septic infections. Prog Clin Biol Res 1989;308:971-6.

11 Rocha E, Paramo JA, Fernandez FJ, et al. Clotting activatio and impairment of fibrinolysis in malignancy. Thromb Res 1989;54:699-707.

12 Asakura $\mathrm{H}$, Saito $\mathrm{M}$, Ito $\mathrm{K}$, et al. Levels of thrombin-antithrombin III complex in plasma in cases of acute promyelocytic leukaemia. Thromb Res 1988;50:895-9.

13 Yver BJ, Samama $M$. Thrombin-antithrombin III complexes for the detection of postoperative hypercoagulable state in surgical patients receiving heparin prophylaxis. Thromb surgical patients receivi

14 Boisclair MD, Ireland $\mathrm{H}$, Lane DA. Assessment of hypercoagulable states by measurement of activation fragments coagulable states by measurement of activg

15 Johnston M, Zipursky A. Microtechnology for the study of the blood coagulation system in newborn infants. Can $\mathcal{7}$ Med Tech 1980;42:159.

16 Lowe GDO, Prentice CRM. The laboratory investigation of fibrinolysis: In: Thomson JM, ed. Blood coagulation and haemostasis. A practical guide. 2nd Ed. Edinburgh: Churchill Livingstone, 1980: 231-2.

17 Rosenberg JS, McKenna $\dot{P}$, Rosenberg RD. Inhibition of human factor IXa by human anti-thrombin-heparin cofactor. F Biol Chem 1975;250:8883-8

18 Damus PS, Hicks M, Rosenberg RD. A generalised view of heparins anticoagulant action. Nature 1973;247:355-7.

19 Stead NW, Kaplan AP, Rosenberg RD. The inhibition of activated factor XII by antithrombin-heparin cofactor. $\mathcal{J}$ Biol Chem 1976;251:6481-8.

20 Bauer KA, Teitel JM, Rosenberg RD. Assays for the quantitation of antithrombin III, thrombin-antithrombin III complex and prothrombin activation fragments. Methods in Hematology 1983:7:142-55.

21 Boisclair MD, Lane DA, Wilde JT, Ireland H, Preston FE, Ofosu FA. A comparative evaluation of assays for markers Ofosu FA. A comparative evaluation of assays for markers of activated coagulation and/or fibrinolysis: thrombin-antithrombin complex, D-dimer and fibrinoge

22 Bain B. Coagulopathies. In: Sherwood Jones B, ed. Intensive care. Lancaster: MTP Press, 1982:78-113. 